\title{
THE JEWISH CALENDAR, A LUNAR ECLIPSE AND THE DATE OF CHRIST'S CRUCIFIXION
}

\author{
Colin J. Humphreys and W.G. Waddington
}

\section{Summary}

Astronomical calculations have been used to reconstruct the Jewish calendar in the first century $A D$ and to date a lunar eclipse that biblical and other references suggest followed the Crucifixion. The evidence points to Friday 3 April AD 33 as the date of the Crucifixion. This was Nisan 14 in the official Jewish calendar, thus Christ died at precisely the time when the Passover lambs were slain. The date 3 April $A D 33$ is consistent with the evidence for the start of Jesus' ministry, with the gospel reference to 46 years to build the temple and with the symbolism of Christ as our Passover lamb. The mention of a solar eclipse at the Crucifixion in some texts of Luke is discussed and explained. A new chronology of the life of Christ is suggested.

\section{Introduction}

The date of the Crucifixion has been debated for many years, but there has been no agreement on the year nor the day. However, astronomy can be used to reconstruct the Jewish calendar in the first century $A D$, and hence to rule out many possibilities. For example, an AD 36 Crucifixion, recently revived by Lane Fox, ${ }^{1}$ appears to be calendrically impossible as will be shown later in this paper. Furthermore, astronomy can be used to identify the most probable date of the Crucifixion. In this paper, which is based on earlier work of the authors, ${ }^{2}$ we use two approaches to dating the Crucifixion: first, a process of elimination, showing that every year but one is incompatible with the available evidence; second, lunar eclipse evidence which positively identifies a particular date. Both approaches yield the same date, 3 April AD 33.

\footnotetext{
${ }^{1}$ R.J. Lane Fox, The Unauthorized Version (London and New York, Viking Penguin 1991).

${ }^{2}$ C.J. Humphreys and W.J. Waddington, 'Dating the Crucifixion', Nature 306 (1983) 743-6; idem, in Chronos, Kairos, Christos: Nativity and Chronological Studies Presented to Jack Finegan, J. Vardaman and E.M. Yamauchi (eds.), (Winona Lake, Eisenbrauns 1989) 172-81.
} 
The date of the Crucifixion is the key date in the chronology of the life of Jesus, since it is directly relevant to the date and nature of the Last Supper, and to the length of his ministry; it is also indirectly relevant to his date of birth. The only certainty is that Jesus' death occurred during the 10 years that Pontius Pilate was procurator of Judea (AD 26-36). There are advocates for nearly every year in this period. 3 In addition to the unknown year, the day of the execution of Jesus is also uncertain since there appears to be a difference of one day between the date given by the Gospel of John and that indicated by the Synoptics.

\section{Biblical Evidence}

There are three main pieces of biblical evidence for dating the Crucifixion:

(i) Jesus was crucified when Pontius Pilate was procurator of Judea during AD 26-36 (all four Gospels; also Tacitus, Ann. 15:44).

(ii) All four Gospels agree that Jesus died a few hours before the commencement of the Jewish Sabbath, that is, he died before nightfall on a Friday. In addition, the earliest writings that explicitly state the date of the Crucifixion all have it as a Friday. 4

(iii) All four Gospels agree to within about a day (see below) that the Crucifixion was at the time of Passover.

In the official festival calendar of Judea, as used by the priests of the temple, Passover time was specified precisely. 5 The slaughtering of the lambs for Passover occurred between 3 p.m. and 5 p.m. on the 14th day of the Jewish month Nisan. The Passover meal commenced at sunset that evening, that is, at the start of Nisan 15 (the Jewish day running from evening to evening; Lv. 23:5, Nu. 28:16). There is, however, an apparent discrepancy of one day in the Gospel accounts of the

3J. Finegan, Handbook of Biblical Chronology (Princeton, Princeton University 1964) 285-301. H.W. Hoehner, Chronological Aspects of the Life of Christ (Grand Rapids, Zondervan 1977) 95-7.

4For a discussion of the three days and three nights of Mt. 12:40, and the arguments against a Wednesday or Thursday Crucifixion, see Hoehner, op. cit., 65-71.

${ }^{5}$ B. Reicke, The New Testament Era (London, Black 1968) 178-9. 
Crucifixion, which has been the subject of considerable debate. In John's Gospel, it is stated that Jesus' trial and execution was the day before Passover (Jn. 18:28; 19:31). Hence John places the Crucifixion on Nisan 14. The correct interpretation of the Synoptics is less clear and we consider briefly three of the many possible interpretations that have been proposed. 6

(a) A straightforward reading of the Synoptics would seem to indicate that the Last Supper was a Passover meal, eaten in the evening at the start of Nisan 15, with the Crucifixion occurring later that Jewish day (that is, still on Nisan 15; e.g. Mk. 14:12). This disagrees with John's date of Nisan $14 .{ }^{7}$

(b) Many scholars propose that the Last Supper described by the Synoptics was not a strict Passover meal. It is suggested that Jesus, knowing of his imminent arrest, held a Passoverlike meal on the evening before Passover (see Lk. 22:15). Supporters of this interpretation note that the Synoptics make no mention of a Passover lamb being slain and roasted for the Last Supper. This interpretation is in broad agreement with the Johannine account in which the farewell meal is explicitly stated to have occurred before the feast of Passover (Jn. 13:1). The timing also agrees, so that on this theory all four Gospels would give Nisan 14 as the Crucifixion date. A number of variations on this basic interpretation exist. 8

(c) A. Jaubert has proposed that the Last Supper reported by the Synoptics was a strict Passover Meal, but held at Passover time as calculated according to the 'sectarian' calendar of the Qumran community and others. 9 According to this theory the Last Supper was held on Tuesday evening, that is, at the start of the Jewish Wednesday (the sectarian calendar Passover day; recorded by the Synoptics), the Crucifixion was on Friday (all four Gospels), and the official Passover was on Saturday (recorded by John). According to this theory all four Gospels

${ }^{6}$ For a review, see I.H. Marshall, Last Supper and Lord's Supper (London, Paternoster 1980) ch. 3.

7J. Jeremias, The Eucharistic Words of Jesus (London, SCM 1966) 15-20.

${ }^{8}$ B. Reicke, New Testament Era, 180-4; F.F. Bruce, New Testament History (London, Thomas Nelson 1969) 183.

${ }^{9}$ A. Jaubert, La Date de la Cène (Paris, Gabalda 1957); see also Finegan, op. cit., 44-9. For a critique of Jaubert's theory see, e.g., R.J. Beckwith, 'The Use of Calendars and Astronomy' in Chronos, Kairos, Christos, 183-205. 
again give Nisan 14 (official calendar) as the Crucifixion date. ${ }^{10}$

Some scholars thus believe that all four Gospels place the Crucifixion on Friday, Nisan 14, while others believe that according to the Synoptics it occurred on Friday, Nisan 15. At this stage for the sake of discussion we assume that both dates may be possible. The problem that then has to be solved is determining in which of the years AD 26-36 the 14th and 15th Nisan fell on a Friday. As is well known, various authors have attempted to use astronomy to provide a solution to this problem. ${ }^{11}$ This is not straightforward however, since, although astronomical calculations can accurately specify the times of new and full moons, we do not know with what skill the Jews of the first century could detect the first faintly glowing lunar crescent following conjunction with the sun (the new moon itself being invisible, of course).

\section{Reconstructing the First Century AD Jewish Calendar}

The Jewish calendar is a lunar calendar, which, in the first century $A D$, was determined by observing the new lunar crescent. Each Jewish month began with the evening when the new crescent was for the first time visible, shortly after sunset. Hence the Jewish day began in the evening, and the first day of each month was the day of first visibility. Consecutive reappearances of the new crescent from its period of invisibility (when it is lost in the glare of the sun) are separated by 29 or 30 days, hence each lunar month is either 29 or 30 days long. The main problem in reconstructing the Jewish calendar is to determine which months were 29 days long and which 30 days.

\footnotetext{
${ }^{10}$ For a discussion of calendars in use in the first century $A D$ see, e.g., E. Schürer, The History of the Jewish People in the Age of Jesus Christ I (rev. ed. by G. Vermes and F. Millar, (Edinburgh, T. \& T. Clark 1973) appendix 3 .

11J. Finegan, op. cit., 291-8; Hoehner, op. cit., ch. 5; E.W. Maunder, 'On the Smallest Visible Phase of the Moon', Journal of the British Astronomical Association 21 (1911) 355; J.K. Fotheringham, 'The Evidence of Astronomy and Technical Chronology for the Date of the Crucifixion', JTS 35 (1934) 146-62; H.H. Goldstine, New and Full Moons, 1001 BC to AD 1651 (Philadelphia, American Philosophical Society 1973).
} 
In our previous work ${ }^{12}$ we computed the visibility of the lunar crescent seen from Jerusalem using the most recent theory, in which we can have considerable confidence. The dates of Nisan 14 for the period AD 26-36 are given in Table 1. Any uncertainties are noted in the footnotes to the table.

Table 1 The date of Nisan 14 in Jerusalem, AD 26-36

\begin{tabular}{|c|c|c|c|c|}
\hline Year (AD) & \multicolumn{2}{|c|}{ New Moon time } & \multicolumn{2}{|c|}{ Deduced date of Nisan 14} \\
\hline 26 & 6 April & $6: 40$ & Sunday & 21 April \\
\hline 27 & $26 \mathrm{March}$ & $20: 05$ & Thursday & 10 April $^{*}$ \\
\hline 28 & 15 March & $\overline{2: 30}$ & Tuesday & $30 \mathrm{March}$ \\
\hline 29 & 2 April & $19: 40$ & Monday & 18 Aprilt \\
\hline 30 & $22 \mathrm{March}$ & 19:55 & Friday & 7 Aprilt \\
\hline 31 & 12 March & $0: 25$ & Tuesday & $27 \mathrm{March}$ \\
\hline 32 & 29 March & $22: 10$ & Sunday & 13 April* \\
\hline 33 & 19 March & $12: 45$ & Friday & 3 April \\
\hline$\overline{34}$ & 9 March & $5: 25$ & Wednesday & $24 \mathrm{March}$ \\
\hline$\overline{35}$ & $28 \mathrm{March}$ & $6: 10$ & Tuesday & 12 April \\
\hline 36 & 16 March & $17: 50$ & Saturday & $31 \mathrm{March}$ \\
\hline
\end{tabular}

The time of new Moon is given as calculated apparent (sundial) time of conjunction for Jerusalem ( $\pm 5 \mathrm{~min}$ ). The deduced date is the Julian day (from midnight to midnight), starting at 6th hour Nisan 14 and ending at 6th hour Nisan 15.

* Nisan 14 AD 27 and AD 32 could have been on the following day if the new Moon was not detected due to poor atmospheric transparency.

t In each of these cases it is not impossible, but highly improbable, that Nisan 14 would have occurred on the preceding day.

Although in the first century $A D$ the beginning of the Jewish lunar month (in the official calendar) was fixed rigorously by astronomical observation, there remain two uncertain calendrical factors: intercalary (or leap) months and the possibility of a cloudy sky rendering the moon invisible. In the case of adverse weather conditions, preventing the observation of the 'new light', the new month commenced on the 31st day of the old one, since the maximum length of any month was 30 days. Hence, although the visibility calculation cannot unambiguously determine that the moon was observed,

12Humphreys and Waddington, op. cit., 743-6; idem, in Chronos, Kairos, Christos: Nativity and Chronological Studies Presented to Jack Finegan, J. Vardaman and E.M. Yamauchi (edd.) (Winona Lake, Eisenbrauns 1989) 172-81. 
it does tell when, even under perfect atmospheric conditions, the moon could not be seen and can thus be used to determine the earliest possible start to each lunar month. (It may be worth adding that the meteorology of a desert region, such as around Jerusalem, gives a high proportion of cloudless nights.) 13

Twelve lunar months total approximately 11 days less than a solar year. For agricultural and religious festival reasons the Jews kept lunar months at approximately the same place in the solar year by the intercalation of a 13th month when necessary. Different methods of intercalation were used at different periods of Jewish history, but in the first century $\mathrm{AD}$ intercalation was regulated annually by proclamation of the Sanhedrin according to certain criteria.14 The most important of these was that Passover must fall after the vernal equinox. If it was noticed (for example, from the position of sunrise or sunset relative to the 'Gates of Heaven' arcs of the Horizon) 15 toward the end of a Jewish year that Passover would fall before the equinox, the intercalation of an extra month before Nisan was decreed. However, a leap month could also be decreed if the crops had been delayed by unusually bad weather (since the first fruits of barley had to be ripe for presentation on Nisan 16) or if the lambs were too young. Unfortunately we possess no historical reports as to the proclamation of leap-months in the years $A D$ 26-36. It is therefore possible that in some years Nisan was one month later on account of unusually severe weather. Our calculations show that in the period AD 26-36, if Nisan was one month later, Nisan 14 would not fall on a Friday in any year and Nisan 15 would only fall on a Friday in AD 34 (23 April).

\section{Possible Dates for the Crucifixion}

Table 2 lists the possible dates of a Friday Crucifixion, on Nisan 14 or 15, and including 23 April AD 34. These dates are

${ }^{13}$ N.V. Vidal and U. Feldman, 'Meteorological Conditions near the Wise Observatory, Israel', Quarterly Journal of the Royal Astronomical Society 15 (1974) 462.

14J. Finegan, op. cit., 42-4; Schürer, op. cit., 1:589-95; Jeremias, op. cit., 37; Fotheringham, 156-7; G. Ogg, The Chronology of the Public Ministry of Jesus (Cambridge, CUP 1940) 263.

15O. Neugebauer, Notes on Ethiopic Astronomy', Or 33 (1964) 50. 
the only ones that are astronomically and calendrically possible for the Crucifixion. Table 2 is identical to the possible dates given by Finegan (based on the calculations of J.K. Fotheringham), 16 except that our more accurate calculations show that Friday, 11 April AD 27, could have fallen on either Nisan 14 or 15, depending upon the atmospheric conditions pertaining at the start of that month. It should be noted from Table 2 that AD 36, recently suggested by Lane Fox ${ }^{17}$ and Kokkinos ${ }^{18}$ for the Crucifixion, is calendrically impossible. Thus a knowledge of the Jewish calendar for the time of Christ is a key piece of information for New Testament studies.

Table 2 Calendrically Possible Dates for the Crucifixion

\begin{tabular}{|c|l|l|}
\hline Jewish Day & \multicolumn{1}{|c|}{ Source* } & Date (Julian Calendar) \\
\hline Nisan 14 & $\begin{array}{l}\text { John's Gospel and } \\
\text { Synoptics (b,c) }\end{array}$ & Friday, 11 April AD 27t \\
\hline & & Friday, 7 April AD 30 \\
\hline & & Friday, 3 April AD 33 \\
\hline Nisan 15 & Synoptics (a) & Friday, 11 April AD 27t \\
\hline & & Friday, 23 April AD 34 $\ddagger$ \\
\hline
\end{tabular}

* Synoptics $(a, b, c)$ refers to the three possible interpretations mentioned on in Finegan, op. cit., 166-67.

+ There is some uncertainty, depending on the atmospheric conditions, as to whether this day was on Nisan 14 or 15 . We include all possibilities for completeness.

$\ddagger$ Only in the case of a leap month being inserted because of exceptionally severe weather (see text).

The year AD 27 is almost certainly too early for the Crucifixion. Luke 3:1-2 carefully states that John the Baptist commenced his ministry in the 15th year of Tiberius Caesar (Jesus was baptized by John subsequently). Since Tiberius was a Roman ruler, and since Luke was writing to Theophilus who appears to have been a Roman official, Luke would probably have reckoned the 15th year of Tiberius according to a Roman calendar. There are then two main possibilities. If Luke was using the Julian calendar and reckoning according to the accession-year system, as used by various Roman historians such as Tacitus, then the 15th year would have been from 1

16J. Finegan, op. cit., 295.

${ }^{17}$ R.J. Lane Fox, op. cit.

${ }^{18}$ N. Kokkinos, 'Crucifixion in AD 36', in Chronos, Kairos, Christos, 133-63. 
January to 31 December AD 29. Alternatively Luke may have used the normal Roman regnal-year method of reckoning, in which case the 15th year would have been from 19 August AD 28 to 18 August $A D 29$. If in fact Luke had used Jewish ecclesiastical reckoning, the 15th year was spring AD 29-30.19 An additional point is that most scholars believe that Pilate had been procurator for some time before the Crucifixion (see Lk. 13:1, 23:12). Thus an AD 27 Crucifixion is highly unlikely.

The year AD 34 is almost certainly too late for the Crucifixion since it would conflict with the probable date of Paul's conversion. We can quite confidently date the later events in Paul's life. Working back from these, and using time intervals given by Paul himself (e.g., three years and 14 years, see Gal. 1:18, 2:1) leads many scholars to infer that Paul's conversion was in $\mathrm{AD} 34 . .^{20}$ In addition, $\mathrm{AD} 34$ is only a possibility for the Crucifixion date if the weather was exceptionally severe. There is no positive evidence in favour of $\mathrm{AD} 34$ and we therefore rule it out.

Having effectively eliminated AD 27 and AD 34 as possible years for the Crucifixion, we note from Table 2 that the Crucifixion must have occurred on Nisan 14 and that the previously listed interpretation (a) of the Last Supper cannot be correct. It is perhaps also worth noting that science has been used here to distinguish between different theological interpretations of the nature of the Last Supper, and has shown on calendrical grounds that the Last Supper cannot have been a Passover meal held at the official Passover meal time. In addition, we have shown that the Crucifixion occurred on Nisan 14, not Nisan 15. Thus Jesus died at the same time as the Passover lambs were slain. This is consistent with many Pauline statements, for example, 'Christ our Passover is sacrificed' (1 Cor. 5:7). In addition, Paul refers to Christ as the first fruits of those who rise from the dead (1 Cor. 15:20), a clear analogy with the offering of the first fruits of barley in the temple, which occurred on Nisan 16. It is unlikely that Paul would have used this symbolism if it were inconsistent with the chronology. Thus, in describing Christ

19O. Edwards, 'Herodian Chronology', PEQ 114 (1982) 29; idem, The Time of Christ (Edinburgh, Floris 1986) 102, 196.

20R. Jewett, A Chronology of Paul's Life (Philadelphia, Fortress 1979, 1979) 30; Edwards, The Time of Christ, 174. 
symbolically as the Passover lamb and as the first fruits, the Pauline chronology of the Crucifixion events (recorded in one of the earliest NT documents, 1 Cor., written in about AD 55) ${ }^{21}$ is identical to that of John. Both are consistent with the synoptic chronology, provided the Last Supper was not a Passover meal held at the official time. In addition, the apocryphal 'Gospel of Peter' states explicitly that Jesus' death was on the eve of Passover, that is, on Nisan 14,22 and a Jewish source, the Babylonian Talmud, records that 'on the eve of Passover they hanged Yeshu', earlier referred to as 'Yeshu the Nazarene' (b. Sanh. 43a; 'Jesus' is the Graeco-Roman equivalent of the Semitic 'Yeshu'). Thus there is a striking unanimity from all sources that the Crucifixion was on Nisan 14 and consequently the only two plausible years for the Crucifixion are AD 30 and AD 33.

Since the ministry of Jesus started after that of John the Baptist, the earliest possible date for the commencement of the ministry of Jesus is autumn AD 28,23 and John's Gospel records three different Passovers occurring during his ministry (including the one at the Crucifixion). Hence, if this evidence is accepted, AD 30 cannot be the Crucifixion year, leaving AD 33 as the only possibility, which year is also consistent with the 'temple reference'. At the first Passover of Jesus' ministry, John 2:20 records that the Jews said to Jesus 'It has taken 46 years to build this temple'. Assuming this refers to the inner temple, the forty-six years leads to the first Passover of Jesus' ministry being in the spring of $\mathrm{AD} 30$ or 31, depending upon how much preparation time was involved before building commenced.24 In addition, an AD 33 Crucifixion is consistent with the known political situation in Judea. ${ }^{25}$ It has puzzled some theologians that at the trials of Jesus, the Gospels depict Pilate as weak and subject to the pressure of the Jews, whereas Josephus, and also

${ }^{21}$ R. Jewett, op. cit., 104; J.A.T. Robinson, Redating the New Testament (London, SCM 1976) 54-5.

22M.R. James, The Apocryphal New Testament (Oxford, Clarendon 1953) 91.

${ }^{23}$ Edwards, The Time of Christ, 104.

${ }^{24}$ Hoehner, (op. cit., 43) gives AD 30; Edwards, (The Time of Christ, 128) gives $\mathrm{AD} 31$, assuming 18 months building preparation time. For an AD 33 Crucifixion these interpretations support a three-year and a twoyear ministry, respectively.

25Hoehner, op. cit., 108-9; Reicke, op. cit., 236. 
Luke 13:1, depict him as ruthless and anti-Semitic. Pilate was appointed procurator of Judea in AD 26 by Sejanus, a noted anti-Semite. Tiberius executed Sejanus for sedition in October $\mathrm{AD} 31$, and subsequently ordered all governors not to mistreat the Jews. Hence the portrayal of Pilate in the Gospels is consistent with the Crucifixion occurring after October AD 31, that is, in $\mathrm{AD}$ 33. If the only Passovers of Jesus' ministry were the three explicitly mentioned in John's Gospel, an AD 33 Crucifixion implies a ministry of about two-and-one-half years. Many scholars believe that John omitted mention of a further Passover, which would imply a ministry of three-andone-half years.

This date, 3 April AD 33, is supported by many scholars. ${ }^{26}$ However, not all scholars accept that AD 33 is preferable to AD 30, and the date 7 April AD 30 is also strongly supported.27 Without further evidence it does not seem possible to decide conclusively between these two dates, although we consider 3 April AD 33 to be the more probable for the reasons given above. In addition, a few scholars support dates other than AD 30 or AD 33, although these do not seem calendrically possible. In order to differentiate between these two calendrically possible dates we now consider the new evidence presented in our previous paper, which, if accepted, provides the first positive dating of the Crucifixion.

\section{The Moon turned to Blood}

The new evidence concerns the meaning and significance of the moon being 'turned to blood', referred to in the Bible and elsewhere. In Acts 2:14-21 it is recorded that on the day of Pentecost the apostles were accused by a crowd of being drunk. Peter stood up and said, No, this is what was spoken by the prophet Joel: In the last days, God says, "I will pour out my spirit on all people. . I will show wonders in the heavens above ... The sun will be turned to darkness and the moon to blood before that great and glorious day of the Lord shall come. And everyone who calls on the name of the Lord shall be saved."'

Commentators are divided upon whether Peter was claiming that all the prophecy quoted from Joel had recently

26Hoehner, op. cit., 145; Reicke, op. cit., 183-4; Ogg, op. cit., 277.

27Finegan, op. cit., 300-1; Bruce, op. cit., 192 n. 2; Robinson, op. cit., 37. 
been fulfilled 28 or whether the words refer to the future. We will investigate the former interpretation further, and demonstrate that 'the moon turned to blood' probably refers to a lunar eclipse, and show that this interpretation is selfconsistent and enables the Crucifixion to be dated precisely.

Peter prefaces his quotation from Joel with the words, 'Let me explain this to you. . .this is what was spoken by the prophet Joel'. Peter therefore appears to be arguing that recent events had fulfilled the prophecy he was about to quote. If this interpretation is correct 'the last days' (17) began with Christ's first advent (for similar usage see 1 Pet. 1:20, Heb. 1:12) and the outpouring of the spirit (17-18) commenced at Pentecost; 'that great and glorious day' (20) refers to the resurrection, since which time 'everyone who calls on the name of the Lord will be saved' (21). 'The sun will be turned to darkness' (20) refers back to the three hours of darkness that occurred only seven weeks previously, at the Crucifixion (Mt. 27:45), and would be understood as such by Peter's audience. As is well known, the mechanism by which the sun was darkened may have been a khamsin dust storm. ${ }^{29}$ In addition, a Messianic section of the Sibylline Oracles, probably written before AD 160, states, 'And straightway dust is carried from heaven to earth, and all the brightness of the sun fails at midday from the heavens' ${ }^{30}$ (This would seem to indicate an early tradition that the darkness at noon was due to a dust storm.) Since the darkened sun occurred at the Crucifixion, it is reasonable to suppose that the moon turned to blood that same evening, 'before that great and glorious day'-the resurrection. This interpretation of Acts 2:20 is supported by the New Testament scholar, F.F. Bruce, who states in his commentary on the Acts, 'Peter's hearers may have associated the phenomena described in vv. 19f. with those which attended the preternatural darkness on Good Friday'. ${ }^{31}$

${ }^{28}$ W. Neil, The Acts of the Apostles (Grand Rapids, Eerdmans 1973), in loc.

${ }^{29}$ G.R. Driver, 'Two Problems in the New Testament', JTS 16 (1965) 3345.

30Sibylline Oracles 3:800-2 in R.H. Charles (ed.), The Apocrypha and Pseudepigrapha of the Old Testament (Oxford, Clarendon 1913) 2:392.

31F.F. Bruce, The Acts of the Apostles (Grand Rapids, Eerdmans 1952), in loc. 
There is some other evidence that on the evening of the day of the Crucifixion the moon appeared like blood. The socalled 'Report of Pilate', a New Testament apocryphal fragment states, 'Jesus was delivered to him by Herod, Archelaus, Philip, Annas, Caiphas, and all the people. At his Crucifixion the sun was darkened; the stars appeared and in all the world people lighted lamps from the sixth hour till evening; the moon appeared like blood' 32

Much of the New Testament Apocrypha consists of highly theatrical literature, which cannot be used as primary historical evidence. Tertullian records that Pilate wrote a report of all the events surrounding the Crucifixion and sent this to the Emperor Tiberias (Apologeticus 5 and 21). The manuscript fragments that we possess of the 'Report of Pilate' are all of later date, but may be partly based on this very early lost document. ${ }^{33}$ If this is the case, the report may provide independent evidence that the moon appeared like blood following the Crucifixion. On the other hand, the report may have used Acts as a source and not be independent from it. If this is the case, however, the event described by Peter is clearly stated in the report to have occurred at the Crucifixion. A third possibility is that the so-called report is a late Christian 'forgery'. If this is correct, there must have been a tradition that at the Crucifixion the moon appeared like blood. Thus whatever the literary status of the 'Report of Pilate', the statement in it that at the Crucifixion the moon appeared like blood has some significance.

Further evidence is provided by Cyril of Alexandria, the orthodox Patriarch of Alexandria in AD 412. After stating that there was darkness at the Crucifixion he adds, 'Something unusual occurred about the circular rotation of the moon so that it even seemed to be turned into blood', and notes that the prophet Joel foretold such signs. ${ }^{34}$ It is concluded that the 'Report of Pilate' and the words of Cyril may be used as

32James, ANT, 154.

33Ibid., 153. See F. Scheideweiler, 'The Gospel of Nicodemus, Acts of Pilate and Christ's Descent into Hell', New Testament Apocrypha, E. Hennecke and W. Schneemelcher, (eds.) (Philadelphia, Westminster 1963) 1:444-9.

34P.E. Pusey, Sancti patris nostri Cyrilli. . in XII Prophetas (Oxford, Clarendon 1868) 1:341-2, on Joel 2:30-31; cited in Driver, op. cit., 333. 
secondary supporting evidence that the moon appeared like blood on the evening of the Crucifixion.

\section{A Lunar Eclipse following the Crucifixion}

The moon turning to blood is a graphic description of a lunar eclipse. The reason an eclipsed moon appears blood-red is well known and the effect has been well documented. Even though during an eclipse the moon is geometrically in the earth's shadow, some sunlight still reaches it by the refraction of light passing through the earth's atmosphere. The light reaching the moon is red since scattering by air molecules and very small particles along its long path through the atmosphere preferentially removes the blue end of the spectrum.

The phrase 'moon turned to blood' has been used by writers and historians to describe lunar eclipses for many centuries, and the expression dates back to at least $300 \mathrm{BC}$. Descriptions of some well-documented ancient eclipses have been compiled by F.K. Ginzel and matched with his calculated eclipse dates. 35 We quote three examples:

(i) The lunar eclipse of 20 September $331 \mathrm{BC}$ occurred two days after Alexander crossed the Tigris and the moon was described by Quintus Curtius (History of Alexander 4:10:2) as 'suffused with the colour of blood'.

(ii) The lunar eclipse of 31 August AD 304, which (probably) occurred at the martyrdom of Bishop Felix, was described in Acta Sanctorum as 'when he was about to be martyred the moon was turned to blood'.

(iii) The lunar eclipse of 2 March AD 462 was described in the Hydatius Lemicus Chronicon thus: 'On March 2 with the crowing of cocks after the setting of the sun the full moon was turned to blood'.

In the medieval European annals compiled by G.H. Pertz there are so many lunar eclipses described by 'the moon turned to blood' that the phrase appears to be used as a

35F.K. Ginzel, Spezieller Kanon der Sonnen- und Mondfinsternisse (Berlin, Mayer und Müller 1899). 
standard description. 36 F.R. Stephenson considers that the prophesy of Joel clearly alludes to a lunar eclipse. ${ }^{37}$

There is therefore strong evidence that when Peter, the 'Report of Pilate', and Cyril of Alexandria refer to the moon turning to blood on the evening of the Crucifixion, they were describing a lunar eclipse. It is surprising that this deduction does not appear to have been made before, although F.F. Bruce almost reaches this conclusion. He states, with reference to Peter's Pentecost speech, 'It was little more than seven weeks since the people in Jerusalem had indeed seen the sun turned into darkness, during the early afternoon of the day of our Lord's Crucifixion. And on the same afternoon the paschal full moon may well have appeared blood-red in the sky in consequence of that preternatural gloom'.38 Presumably Bruce and other commentators have not been aware that a blood-red moon is a well-documented description of a lunar eclipse.

\section{Lunar Eclipses visible from Jerusalem AD 26-36}

We have determined the eclipses relevant to our work by the use of J. Meeus and H. Mucke's Canon of Lunar Eclipses, the most comprehensive data available, as corrected by F.R. Stephenson and L.V. Morrison, who used ancient Babylonian eclipse records to refine the calculations to take into account more accurately the long-term changes in the earth's rate of rotation.39 These calculations agree very well with records of Babylonian and Chinese eclipse observations (the probable error in an eclipse time 2000 years ago is typically five minutes). All lunar eclipses (total and partial) visible from Jerusalem between AD 26 and AD 36 are listed in Table 3 which shows that in the period AD 26-36 there was one, and only one,

${ }^{36}$ G.H. Pertz (ed.), Monumenta germaniae historica. . .scriptorum (Hanover, Hahn 1826-1934; repr. New York, Kraus 1963), vols. 16-19.

37F.R. Stephenson, 'The Date of the Book of Joel', VT 19 (1969) 224.

${ }^{38}$ F.F. Bruce, Commentary on the Book of the Acts NICNT (Grand Rapids, Eerdmans 1981) in loc.

${ }^{39} \mathrm{~J}$. Meeus and H. Mucke, Canon of Lunar Eclipses: -2002 to +2526 (Vienna, Astronomy Buro 1983); F.R. Stephenson and L.V. Morrison, 'Long-term Changes in the Rotation of the Earth: 700 BC to AD 1980', Philosophical Transactions of the Royal Society of London A313 (1984) 47; idem, 'History of the Earth's Rotations since 700 BC', in P. Brosche and J. Sundermann (eds.), Tidal Friction and the Earth's Rotation (Berlin/New York, Springer Verlag 1982) 2:29-50. 
lunar eclipse at Passover time visible from Jerusalem, namely that of Friday, 3 April AD 33. This date is the most probable date for the Crucifixion deduced independently using other data (see section IV). The interpretation of Peter's words in terms of a lunar eclipse is therefore not only astronomically and calendrically possible, but it also allows us with reasonable certainty to specify Friday, 3 April AD 33, as being the date of the Crucifixion. The random probability of a lunar eclipse occurring at moon rise on a particular date is, of course, small.

Table 3 Lunar eclipses visible from Jerusalem AD 26-36

\begin{tabular}{|l|l|l|c|c|}
\hline \multicolumn{2}{|c|}{ Date* } & \multicolumn{1}{c|}{ Dayt } & Magnitude & $\begin{array}{c}\text { Time eclipse } \\
\text { started }\end{array}$ \\
\hline 15 Aug. & AD 26 & Friday & $50 \%$ & 23.10 \\
\hline 31 Dec. & AD 27 & Wednesday & $70 \%$ & 23.27 \\
\hline 14 June & AD 29 & Tuesday & Total & 20.27 \\
\hline 9 Dec. & AD 29 & Friday & $45 \%$ & 20.55 \\
\hline 25 April & AD 31 & Wednesday & $35 \%$ & 21.35 \\
\hline 19 Oct. & AD 31 & Friday & $25 \%$ & 4.49 \\
\hline 3 April & AD 33 & Friday & $60 \%$ & $\begin{array}{c}\text { Occurred at } \\
\text { rising Moon }\end{array}$ \\
\hline 27 Sept. & AD 33 & Sunday & $85 \%$ & 4.53 \\
\hline 11 Feb. & AD 35 & Friday & $55 \%$ & 4.55 \\
\hline 7 Aug. & AD 35 & Sunday & $60 \%$ & 20.18 \\
\hline 31 Jan. & AD 36 & Tuesday & Total & $\begin{array}{c}\text { Occurred at } \\
\text { rising Moon }\end{array}$ \\
\hline 26 July & AD 36 & Thursday & Total & 22.14 \\
\hline
\end{tabular}

* Julian Calendar

+ Julian day (from midnight to midnight as distinct from the Jewish day).

$\ddagger$ Fraction of the area of the Moon covered at the midpoint of the eclipse.

It is interesting to note that there have been a few references to this eclipse in the past, for example, J.R. Hind calculated that there was a lunar eclipse on 3 April AD 33, however his calculations showed that this eclipse was not visible from Jerusalem, and hence it was considered irrelevant to the date of the Crucifixion. 40 However, the calculations of Hind were inaccurate and it is only recently, especially

40J.R. Hind, 'Historical Eclipses', Nature 6 (1872) 251. 
following the work of F.R. Stephenson, 41 that we have been able accurately to take into account the effects of long-term changes in the earth's rate of rotation. 42 We can now state with confidence that this lunar eclipse would have been visible from Jerusalem: that is its importance.

\section{The Lunar Eclipse on Friday, 3 April AD 33}

Calculations show that the eclipse on 3 April AD 33 was visible from Jerusalem at moonrise. (All times quoted below are local Jerusalem times as measured by a sundial.) The start of the eclipse was invisible from Jerusalem, being below the horizon. The moon rose above the Jerusalem horizon at about 6:20 p.m. (the start of the Jewish Sabbath and also the start of Passover day in $\mathrm{AD} 33$ ), with about $20 \%$ of its disc in the umbra of the earth's shadow and the remainder in the penumbra. The ancients, however, made no distinction between the umbral and penumbral shadows and to a casual observer about 60 per cent of the moon's disc would have been perceived as being 'in eclipse' at moonrise. The perceived eclipse ended at about 7:10 p.m. The 60 per cent 'bite' out of the moon was positioned close to the top (that is, leading edge) of the moon. Thus most of the visible area of the rising moon would initially have been seen as fully eclipsed.

There is great variability in exact coloration from eclipse to eclipse owing to atmospheric conditions. As explained previously, the umbral shadow is normally bloodred. However, this colour is most noticeable during total lunar eclipses. For partial eclipses, particularly with the moon at high altitude against a starry background, there is a large contrast between the obscured and unobscured part of the moon, so that the moon often appears almost white with a very dark 'bite' removed. However, for some partial eclipses the red colour of the umbral shadow is clearly visible. For example, D. Davis has depicted in colour an eclipse sequence as seen by the human eye with the moon low in the sky; the

41Stephenson and Morrison, 'Long-term Changes in the Rotation of the Earth'; Stephenson, 'Historical Eclipses', Scientific American 247.4 (1982) 154-63 [American edition pp. 171-73].

42Stephenson and Morrison, 'History of the Earth's Rotation', 45. 
coloration of the umbra in the partial eclipse phase is almost as vivid as when the eclipse is total.43

For the case of the eclipse of 3 April AD 33 the moon was just above the horizon and was seen against a relatively bright sky background (the sun having just set). The most probable colour of the rising moon would be red in the umbral shadow and yellow-orange elsewhere. At moonrise the initially small yellow-orange region would indicate that the moon had risen, but with most of its visible area 'turned to blood'. If in fact a massive dust storm was responsible for darkening the sun, and this storm subsided at about 3 p.m. (the darkness is recorded in the Gospels to have lasted from noon to 3 p.m.), any dust still suspended in the atmosphere would tend to modify the above colours. The nature of such a modification would depend upon the size distribution of the particles.

The majority of lunar eclipses pass unnoticed, occurring when people are asleep or indoors. This eclipse, however, would probably have been seen by most of the population of Israel, since the Jews on Passover Day would be looking for both sunset and moonrise in order to commence their Passover meal. Instead of seeing the expected full Paschal moon rising, they would have initially seen a moon with a red 'bite' removed. The effect would be dramatic. The moon would appear to grow to full in the next hour. The crowd on the day of Pentecost would undoubtedly understand Peter's words about the moon turning to blood as referring to this eclipse that they had seen.

\section{The Apparent Mention of a Solar Eclipse in some Texts of Luke's Gospel}

Whereas Mark 15:33 records the three hours of darkness accompanying the Crucifixion without comment-as if there were nothing particularly untoward about its occurrenceLuke 23:45 apparently appends, by way of explanation, a specific reference to a solar eclipse. As is well known, such an event is a scientific impossibility at Passover (full moon) time, and we give two possible explanations below.

${ }^{43} \mathrm{D}$. Davis's illustration accompanying D. di Cicco, More about July's Lunar Eclipse', Sky and Telescope 64 (1982) 391. 
In addition to the earliest known Lucan papyrus (ca. AD 200), all the major manuscripts of Luke's Gospel (Sinaiticus, Vaticanus, Ephraemi [C], and L) contain what appears to be the standard technical description of a solar

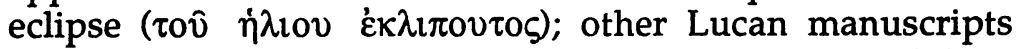
dating from before AD 900, however, lack any trace of these three words. Moreover, recent computer-based textural analysis of these primary manuscripts shows that the early papyrus p75 is closely related to Vaticanus and often also to Sinaiticus, as well as to $L$ and perhaps also to C.44 It would thus appear that the specific reference to a solar eclipse was established uniquely in one family of the Lucan text by about AD 200 and is absent from all other families of related manuscripts. Furthermore, since the three words in question occur at the end of an otherwise complete sentence, and apparently refer to a scientific impossibility, it is possible they are an intrusion in p75 and its related manuscripts, rather than being an intrinsic part of the original Lucan text that was later replaced by a more general phrase ( $\varepsilon \sigma \kappa o \tau \iota \sigma \theta \eta$ ó $\left.\dot{\eta} \lambda \iota \varsigma^{\prime}\right)$ in the other manuscript families.

Since the occurrence of a solar eclipse at Passover time has long been known to be astronomically impossible, but that of a lunar eclipse may well occur, it is possible that the apparent mention of a solar eclipse in some Lucan manuscripts is a direct result of confusion arising from a widespread tradition of an eclipse at the Crucifixion.45 In this respect it is, perhaps, significant that, in attempting to identify the cause of the Crucifixion darkness as a solar eclipse, Julius Africanus (Chronicon 50) erroneously attributed to Phlegon the statement that the eclipse noted by him occurred at full moon; this particular eclipse (Phlegon's eclipse) was subsequently identified by Kepler as that of 24 November AD 29, in spite of the AD 32-33 date given by Phlegon.

The lunar eclipse of 3 April AD 33 may thus explain the curious reference to a Crucifixion solar eclipse in some manuscripts of the Luke text, which may be an intrusion inserted by a scribe knowing the oral tradition of a Crucifixion eclipse without appreciating that it was in fact a lunar eclipse.

${ }^{44}$ As communicated personally to us by J.G. Griffith.

${ }^{45}$ Fotheringham, op. cit., 160-1. 
An alternative explanation is that the Greek word

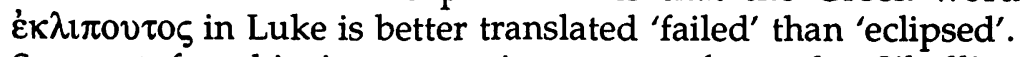
Support for this interpretation comes from the Sibylline Oracles quoted earlier, where the same verb is translated 'failed' in R.H. Charles's Apocrypha and Pseudepigrapha of the Old Testament, and clearly the darkening mechanism in the Oracles is a dust storm not an eclipse.46 On this interpretation, the problem with Luke's apparent mention of a solar eclipse in some manuscripts disappears since the work translated 'eclipsed' is better translated 'failed'.

\section{Some Implications of the Crucifixion Lunar Eclipse}

In ancient times eclipses (total or partial) were regarded as a supernatural sign, often associated with the wrath of a god. For example, the first-century Jewish historian Flavius Josephus records that a lunar eclipse occurred on the same night as Herod the Great burnt alive Matthius and some other Jews for sedition (Antiquities 17:167).47 A lunar eclipse on the same night as the Crucifixion would similarly have been interpreted by many as a supernatural sign associated with the wrath of God. This eclipse may well have been an important factor producing the overnight change of mind of the Jews and Pilate toward the body of Jesus, leading to the placing of the guard on the tomb, although previously Joseph of Arimathaea had apparently had no difficulty in obtaining the body for burial.

We have already noted the symbolism of Christ as the Passover lamb and the first fruits. The lunar eclipse may provide further symbolism in that it provides a striking parallel between the Crucifixion and the original Passover. The last plague before the Passover was three days of darkness, 'darkness that can be felt' (Ex. 10:21), which again could have been a massive dust storm, or possibly a volcanic ash cloud. The Passover lamb was slain toward the end of Nisan 14. This was followed by blood being smeared on the door frames: 'the blood will be a sign for you' (Ex. 12:13). At the Crucifixion there was three hours of darkness, then the Lamb of God died toward the end of Nisan 14. This was followed by the moon

${ }^{46}$ Charles, op. cit., 2:392.

${ }^{47}$ Ginzel (op. cit., 127) takes this to be the partial eclipse of 13 March 4 BC. 
'turning to blood', which could have been regarded as 'a sign for you'.

\section{A new Chronology of the Life of Christ}

In a previous paper ${ }^{48}$ we dated the birth of Christ to the Spring of $5 \mathrm{BC}$. In the present paper we have dated his death to 3 April AD 33. These two key dates enable a new chronology of the life of Christ to be constructed which is given in Table 4. The most likely date for the baptism of Jesus is autumn AD 29.49 If Jesus was born in the Spring of $5 \mathrm{BC}$ then he would have been 33 when he commenced his ministry, which is consistent with Luke 3:23 that he was 'about thirty' at this time (the Greek translated 'about thirty' is an imprecise expression meaning any age between 26 and 34). It should also be remembered that there is no year ' 0 ' between $1 \mathrm{BC}$ and $\mathrm{AD} 1$ in our conventional calendar. If the Crucifixion was on 3 April AD 33 then Jesus was close to his 37 th birthday when he died.

\section{Conclusions}

Establishing the precise date of any ancient event is well known to be extremely difficult. It is probably not an exaggeration to state that only when ancient chronology is based upon calculable astronomical phenomena can we have certainty and precision. In this article, astronomy has been applied in two different ways to date the Crucifixion. First, in reconstructing the first-century-AD Jewish calendar and, second, in determining that there was a lunar eclipse visible from Jerusalem at moonrise on the evening of one of the only two days considered to be calendrically possible for the Crucifixion: Friday, 3 April AD 33. If this date was indeed the date of the Crucifixion we would expect some textual reference to this lunar eclipse. This article presents three such textual references: the Acts of the Apostles, the 'Report of Pilate', and the writings of Cyril of Alexandria. There are therefore strong convergent arguments pointing to 3 April AD 33 as being the date of the Crucifixion.

${ }^{48} \mathrm{C}$.J. Humphreys, "The Star of Bethlehem, a Comet in $5 \mathrm{BC}$ and the Date of Christ's Birth', TynB 43.1 (1992) 31-56.

${ }^{49}$ Finegan, op. cit., 270 and 301; P.L. Maier, 'The Date of the Nativity and the Chronology of Jesus' Life', in Chronos, Kairos, Christos, 124. 
Table 4 Chronology of the Life of Jesus

\begin{tabular}{|l|l|}
\hline Date in Julian Calendar & \multicolumn{1}{|c|}{ Event } \\
\hline $\begin{array}{l}\text { 9 March - 4 May 5 BC } \\
\text { (13-27 April 5 BC) }\end{array}$ & $\begin{array}{l}\text { Birth of Jesus in Bethlehem and visit } \\
\text { of the Shepherds }\end{array}$ \\
\hline $\begin{array}{l}\text { 20 April - 15 June 5 BC } \\
\text { (24 May - 8 June 5 BC) }\end{array}$ & Visit of the Magi \\
\hline $\begin{array}{l}\text { Late April - mid June 5 BC } \\
\text { (Late May - mid June 5 BC) }\end{array}$ & Flight to Egypt \\
\hline end of March 4 BC & Death of Herod \\
\hline March (?), 3 BC & Return from Egypt to Nazareth \\
\hline * April 1 BC & Jesus' fourth birthday \\
\hline * April AD 1 & Jesus' fifth birthday \\
\hline AD 29 & $\begin{array}{l}\text { Fifteenth year of Tiberius, when John } \\
\text { the Baptist started his ministry (Lk. 3:1) }\end{array}$ \\
\hline$\sim$ April AD 29 & Jesus' 33rd birthday \\
\hline Autumn (?) AD 29 & $\begin{array}{l}\text { Baptism of Jesus when 33 ('about } \\
\text { thirty', Luke 3:23) }\end{array}$ \\
\hline March AD 30 & $\begin{array}{l}\text { First Passover of Jesus' ministry, 46 } \\
\text { years after the priests finished building } \\
\text { the inner temple (Jn. 2:20) }\end{array}$ \\
\hline Friday, 3 April AD 33 & $\begin{array}{l}\text { Crucifixion on Nisan 14 when Jesus } \\
\text { was near his 37th birthday }\end{array}$ \\
\hline & \\
\hline
\end{tabular}

\section{Notes:}

(i) The dates given in brackets are the narrower date ranges based on Jesus being born around Passover time (see ref. 46).

(ii) * included to illustrate the absence of year ' 0 ' 